\title{
Assessment of Influence of Extension Teaching Methods on the Level of Adoption of Agricultural Innovation in Akwa-Ibom State, Nigeria
}

\author{
Umeh, O.J ${ }^{1}$, Aghale, D. $\mathbf{N}^{2}$. \& Anyim, $\mathbf{A}^{3}$. \\ ${ }^{l}$ Department of Rural Sociology and Extension, Michael Okpara University of Agriculture, Umudike \\ ${ }^{2}$ Department of Plant Science and Biotchnology, Michael Okpara University of Agriculture, Umudike \\ ${ }^{3}$ Agric Department, Ministry of Agriculture and Rural Department, Abia State, Nigeria.
}

*Corresponding Author: Umeh, O.J, Department of Rural Sociology and Extension, Michael Okpara University of Agriculture, Umudike

\begin{abstract}
Assessment of influence of extension teaching methods on the level of adoption of agricultural innovation was conducted in Akwa-Ibom State, Nigeria in 2017. Specifically, the study identified extension teaching methods used by extension agents in the study area in disseminating improved practices to farmers; determined extent of adoption of the recommended practicesby farmers in relation to cassava /maizel telferia inter-crop production and ascertained factors militating against adoption of extension recommendations in the area. Multistage sampling techniques were used in selecting 180 respondents for the study. Descriptive statistics was used for data analysis while Probit regression analysis was used to test the hypothesis. The results shows thatgroup methods (demonstration, field shows, etc) were the major (53\%) extension teaching method used by extension agents in the area, however only, only use of improved variety of cassava $(\bar{x}=3.4)$, processing and value addition $(\bar{x}=3.1)$ and fertilizer application $(\bar{x}=2.9)$ out of the eleven recommended practices presented to the respondents for the production of cassava /maizel telferia inter-crop were adopted.Probit regression estimates showed that the coefficient for mass method (5.279***) was positive and highly significant at $1 \%$ level of probability with rate of adoption by the farmers, implying that increase in the use of mass method will lead to increase in adoption of agricultural innovations in the study area. It was therefore recommended that extension personnel must acquire the requisite knowledge and skills necessary for using modern ICTs in the discharge of their job functions.
\end{abstract}

Keywords: extension teaching methods, adoption, agricultural innovation.

\section{INTRODUCTION}

Successive governments in Nigeria seemed to have recognized the importance of agricultural extension for the survival of the small scale farmers. This could be seen in the involvement of both Federal and State governments in the formulation and implementation of agricultural development policies and programmes with extension components. This was to increase the productivity and level of income of the farmers, but not many farmers benefited from these programmes as the programmes were not properly planned and executed (Ali, 1989). The goal of agricultural extension is to disseminate agricultural technologies for improving productivity, farmers' welfare and household nutritional status (Fabiyi, 2015).

In the light of the above, extension has been recently defined as "systems that facilitate the access of farmers, their organizations and other market actors to knowledge, information and technologies; facilitate their interaction with partners in research, education, agribusiness, and other relevant institutions; and assist them to develop their own technical, organizational and management skills and practices". (Christoplos, 2010). Strengthening the exchange of information and knowledge between farmers, community groups, research institutes and intermediary organisations (such as NGOs and government extension agencies) is a necessity for effective implementation of extension agenda. Therefore, strategies and tools for improving local access to high-quality agricultural knowledge are a prerequisite for improving livelihoods and reducing vulnerability. First, there is need to identify range of approaches and methodologies for developing strategies for getting research into use in the rural 
areas. Also, identify communication/method of delivery and promotional strategies that widened access by all stakeholders to new products and knowledge. However, ineffective agricultural extension services has been identified as major constrain to the performance of the agricultural sector (Forth National Development Plan, (1985), while one of the serious problems in Nigeria agricultural extension services was the rate at which available research results were transferred to farmers (Ayesha and Mohammad, 2012)

Agriculture is the mainstay of the people of the study area. Despite all the efforts made by governments to increase agricultural production by creating awareness of improved farm technologies among peasant farmers through agricultural extension services, the researcher observed that many farmers in the study area are still farming in the same old way as their ancestors. That is, planting the same local seeds, using the same traditional planting and storage methods, keeping the same local breed of plants and animals. In addition they depend largely on family labour due to unavailability and high cost of tractor hiring services. It is based on these problems that the researcher carried out a research to evaluate the influence of extension teaching methods on the level of adoption of agricultural innovation in Akwa-Ibom State, Nigeria.

Objectives

i. identify the extension teaching methods used by extension agents in the area in disseminating the improved practices to farmers,

ii. determine the extent of adoption of the recommended practices by the farmers in relation to cassava and maize production and

iii. ascertain factors militating against the adoption of extension recommendations in the area.

Hypotheses

Ho $_{1}$ : There is no significant relationship between the extension teaching methods used by extension agents in disseminating the improved practices, and the rate of adoption by the farmers.

\section{Methodology}

The study was conducted in Akwa Ibom State. Akwa Ibom State is located in the coastal South-South region of Nigeria. The region is popularly called the Niger Delta region or the oil rich region of Nigeria. The state is located between latitudes $4^{\circ} 321^{\mathrm{c}}$ and $5^{\circ} 331^{\mathrm{c}}$ north and longitudes $7^{\circ} 51^{\mathrm{c}}$ and $8^{\circ} 251^{\mathrm{c}}$ east. It has a total land area of areas of $7,246 \mathrm{~km} 2$. It is bordered on the east by Cross River State, on the west by Rivers State and Abia State, and on the South by the Atlantic Ocean. Akwa Ibom State has a population of about 3,902,051 (NPC, 2006). The main crops grown in the area include cassava, cocoyam, yam, maize, melon, okra and vegetables (green, fluted pumpkin, water-leaf and bitter leaf). The live-stocks reared include; sheep, goats, fishes, pigs and poultry.

\section{Sampling procedure}

The multi - stage sampling technique were employed in the selection of the respondents for the study. In the first stage, Akwa Ibom state is stratified into three (3) agricultural zones namely Ikot Ekpene, Uyo and Oron. Two agricultural zones were randomly selected. The second stage involved the random selection of six (3) blocks from each of the selected agricultural zone. In the third stage, five (5) circles were randomly selected from each of the blocks earlier selected. Finally, six (6) cassava farmers were randomly selected from each circle and this gave a sample size of 180 respondents. Primary data for the study were collect through the use of questionnaires issued to respondents in the study area.

\section{Method of data analysis}

Objective (i) which is to identify the extension teaching methods used by extension agents in the area in disseminating the improved practices to farmers will be analyzed with descriptive statistic such as frequencies and percentages.

Objective (ii) which is to determine the extent of adoption of the recommended practices by the farmers in relation to cassava and maize production will be analyzed using mean. To derive the mean, 
recommended practices for cassava /maize/ telferia inter-crop production were scaled in a four point likert-type scale of highly adopted (4 points), moderately adopted ( 3 points), poorly adopted ( 2 points) and not adopted (1 point). The objective was analyzed using mean score. Values of the points were summed to get 10 and divided by the number of values to get 2.5 as the mean. Items with mean score of less than 2.5 were categorized as not adopted while items with mean score of 2.5 and above were categorized as adopted.

Objectives (iii) which is to ascertain the factors militating against the adoption of extension recommendations in the study area will be measured by scaling list of problems in a 5-points Likert Scale of very high (5), high (4), moderate (3), low (2) and very low (1) and analyzed using mean. The values were summed to get 15 and divided by the number of values to get 3 as the mean. The likert scaling is a method of ascribing quantitative values to qualitative perception to make it amenable to statistical analysis. Variables with decision score of 3.0 and above will be accepted as constraints but variables with decision score of less than 3.0 are not regarded as a constraint.

Probit analysis were used to test the null hypothesis $\mathbf{H}_{\mathbf{0 1}}$ that there is no significant relationship between the extension teaching methods used by extension agents in disseminating the improved practices, and the rate of adoption by the farmers.

\section{Model specifications}

Probit regression model is explicitly stated thus;

$\mathrm{Yi}^{*}=\mathrm{B} 1 \mathrm{xi}+\mathrm{E}$

$\mathrm{Yi}^{*}=0$ if $\mathrm{Yi}^{*}=0$

$\mathrm{Yi}=1$ if $\mathrm{Yi}^{*}=0$

Where:

$\mathrm{Yi}^{*}=$ an underlying latent variable that indexes effectiveness of the scheme

Yi $=$ dummy variable indexing adoption of recommendations by the farmers. (Dichotomous dependent variable $1=$ yes, $0=$ No)

$\mathrm{B} 1=\mathrm{a}$ vector of estimated parameter

$\mathrm{E}=$ the error term

$\mathrm{Xi}=$ individual farmers variables considered in the study include;

$\mathrm{X} 1$ = Individual method

$\mathrm{X} 2$ = group method

$\mathrm{X} 3$ = mass method

$\mathrm{X} 4=$ combination of group and individual methods

$\mathrm{Ei}=$ error term

\section{Extension teaching methods used by extension agents in the study area}

Data from Table 1 indicate that group methods (demonstration, field shows, etc) (53\%) and combination of individual and group methods $(23 \%)$ are the major teaching met methods used by extension agents in dissemination of information in the study area. Group methods offered the possibility of greater extension coverage within the rural community because large number of farmers could be reached at a time, and therefore were very appropriate for teaching skills to farmers. Garba, (2008) agreed that group and demonstration methods are very effective methods of propagating improved practices to farmers, the farmers were shown how to do something step-by-step that is, in sequence for instance how to spray insecticides or apply fertilizers. Group method within the rural setting also encouragesparticipation in extension teaching program and transmission of innovations from farmer to farmer within the neighborhood. However, use of ICTs and its components such as Tv /radio broadcasts, posters/leaflets, mobile phones which is mass method was very low. 
Assessment of Influence of Extension Teaching Methods on the Level of Adoption of Agricultural Innovation in Akwa-Ibom State, Nigeria

Table 1. distribution of extension teaching methods used by extension agents in the area

\begin{tabular}{|l|l|l|l|}
\hline s/n & Extension teaching methods & Frequency & Percentage \\
\hline 1 & Individual method (farm/home visits, calls, etc) & 18 & 10 \\
\hline 2 & Group methods (demonstration, field shows, etc) & 96 & 53 \\
\hline 3 & $\begin{array}{l}\text { Mass methods (ICT, Tv /radio broadcasts, posters/leaflets, } \\
\text { mobile phones etc) }\end{array}$ & 25 & 14 \\
\hline 4 & Combination of individual and group methods & 41 & 23 \\
\hline \multicolumn{2}{|l|}{ Source: Field Survey 2017 }
\end{tabular}

\section{Extent of adoption of the recommended practices by the farmers in relation to cassava /maize/ telferia inter-crop production}

The extent of adoption of the recommended practices by the farmers in relation to cassava /maize/ telferia inter-crop production was examined. Findings presented in table 2 revealed that only three out of the eleven recommended practices presented to the respondents for the production of cassava /maize/ telferia inter-crop were adopted. They areuse of improved variety of cassava $(\mathrm{m}=3.4)$, processing and value addition $(\mathrm{m}=3.1)$ and fertilizer application $(\mathrm{m}=2.9)$. This shows that the package has not fully been adopted, therefore the extension agents has not done enough using the group and individual extension teaching methods in the study area. This result is in agreement with the researcher's base line observation that many farmers in the study area are still farming in the same old way as their ancestors. That is, planting the same local seeds, using the same traditional farming methods, keeping the same local breed of plants and animals. The findings of this study have a lot of implications for extension especially now that there is an urgent need to reduce hunger and poverty in Nigeria. In agreement, Ayesha and Mohammad (2012) reported that in many developing countries, wide adoption of research results by majority of farmers remains quite limited. There is therefore need for regular training, in form of workshops, seminars, conferences and in-service training for extension agents to acquire more knowledge and experience in group dynamics, adult learning principles and appropriate combination of extension-teaching methods for rapid farm-technology diffusion and sustained productivity growth.

Table 2. mean distribution of extent of adoption of the recommended practices by the farmers in relation to cassava /maize/ telferia inter-crop production

\begin{tabular}{|l|l|l|l|l|}
\hline $\mathrm{s} / \mathrm{n}$ & & Total & Mean & SD \\
\hline 1 & Site selection & 258 & 1.4 & 0.6296 \\
\hline 2 & Land preparation & 310 & 1.7 & 0.6981 \\
\hline 3 & Use of improved variety of Cassava & 651 & 3.4 & 0.6711 \\
\hline 4 & Use of improved variety of Maize & 355 & 1.9 & 0.6728 \\
\hline 5 & Use of improved variety of Telferia & 242 & 1.3 & 0.6933 \\
\hline 6 & Plant spacing & 420 & 2.3 & 0.7093 \\
\hline 7 & Fertilizer application & 517 & 2.9 & 0.6835 \\
\hline 8 & Weeding & 420 & 2.3 & 0.7417 \\
\hline 9 & Pesticides application & 310 & 1.7 & 0.5650 \\
\hline 10 & Harvesting & 355 & 1.9 & 0.7771 \\
\hline 11 & Processing and value addition & 559 & 3.1 & 0.7100 \\
\hline
\end{tabular}

Source: Field Survey 2017

\section{Factors militating against the adoption of extension recommendations}

Table 3 indicates that major factors militating against adoption of extension recommendations in the study area are irregular training and visit by the extension agents $(\mathrm{m}=4.4)$, lack of adequate technical knowledge about recommended farm practices $(\mathrm{m}=4.0)$ and delay in receipt of production inputs $(\mathrm{m}$ =3.7). Others are unavailability of recommended farm inputs $(\mathrm{m}=3.1)$ and Cost of agro-inputs $(\mathrm{m}=$ 2.6).The result implies that major limitations to adoption of recommendations by farmers hinges on the role of extension agents in discharging their extension activities and delay in receipt of production inputs. Garba (2008) agreed that lack of necessary input was the most serious problems why some farmers in the study did not adopt the improved farm practice introduced to them. Akinagbe, (2010) asserted that the problems that emanate from agriculture at grass root levels are transfer of innovations by the extension personnel and how improved technology are disseminated to the farmers for implementation. 
Assessment of Influence of Extension Teaching Methods on the Level of Adoption of Agricultural Innovation in Akwa-Ibom State, Nigeria

Table 3. Mean distribution of factors militating against the adoption of extension recommendations in the area

\begin{tabular}{|l|l|l|l|l|}
\hline s/n & variables & Total & mean & SD \\
\hline 1 & Cost of land & 422 & 2.3 & 0.7069 \\
\hline 2 & Unavailability of recommended farm inputs (eg. Fertilizer) & 560 & 3.1 & 0.8786 \\
\hline 3 & Cost of labour & 431 & 2.4 & 0.7989 \\
\hline 4 & Lack of ready market to sell & 385 & 2.1 & 0.4902 \\
\hline 5 & Cost of agro-inputs & 471 & 2.6 & 0.6181 \\
\hline 6 & $\begin{array}{l}\text { Lack of adequate technical knowledge about recommended } \\
\text { farm practices. }\end{array}$ & 728 & 4.0 & 0.9025 \\
\hline 7 & Some practices run contrary to our needs & 451 & 2.5 & 0.9056 \\
\hline 8 & Inadequate rains & 396 & 2.2 & 0.5795 \\
\hline 9 & Lack of cooperation from local leaders & 422 & 2.3 & 0.8009 \\
\hline 10 & Lack of cooperation from farmers & 390 & 2.2 & 0.7676 \\
\hline 11 & Delay in receipt of production inputs & 660 & 3.7 & 0.7689 \\
\hline 12 & Irregular training and visit by the extension agents & 800 & 4.4 & 0.7771 \\
\hline
\end{tabular}
Source: Field Survey 2017

\section{Relationship between the extension teaching methods used by extension agents in disseminating improved practices, and the rate of adoption by the farmers}

The result in Table 4 shows the Probit regression estimates of the relationship between the extension teaching methods used by extension agents in disseminating improved practices, and the rate of adoption by the farmers. This functional form was chosen as the lead equation based on a high $\mathrm{R}^{2}$ value, number of significant variables and agreement with a priori expectation. The $\mathrm{R}^{2}$ value of 0.60 indicating $60.0 \%$ variability in perception is explained by the independent variables. The F-value (57.351) was highly significant at $1 \%$ level of probability indicating goodness of fit of the regression model. The coefficient for mass method (5.279***)was positive and highly significant at $1 \%$ level of probability. This implies that increase in the use of mass method will lead to increase in adoption of agricultural innovations in the study area.

Result of the analysis implies that mass method will greatly enhance adoption of technologies and agro- information by farmers as against the use of group method which is widely used by extension agents in the study area. In agreement, Umeh (2016) also ranked mass media method most effectiveof different extension services delivery methods used by extension personnel. Mass method involves the use of Information and communication technology (ICT) to reach out to wider range of audience thereby increasing rate of adoption of required information. In agreement to this result, CTA (2013) reported that ICTs have the potentials to enhance farmers' ability to collate demands; collaborative learning; exchange of time sensitive information, for example, market prices and disease outbreaks; make extension systems and structures more efficient; engage farmers in assessing own needs, solutions; exploring alternative production technologies; facilitating access to markets and credits; training and demonstration; early warning for disasters, weather forecast; and peer to peer sharing and exchange among extension. Furthermore, Umar et al (2015) agreed thatagricultural extension has to escape from the narrow mindset of transferring technology packages to transferring knowledge or information packages. If this can be achieved, with the help of Information and Communication Technology (ICT), extension will become more diversified, more knowledge-intensive, and more demand driven, and thus more effective in meeting farmers' information needs thereby encourage high rate of adoption of cassava /maize/ telferia inter-crop production and other extension packages inclusive.

Table 4. Probit regression estimate of the relationship between the extension teaching methods used by extension agents in disseminating the improved practices, and the rate of adoption by the farmers

\begin{tabular}{|l|l|l|l|}
\hline Parameter & Coefficient & Standard error & t-values \\
\hline Individual method & .195 & .315 & 0.384 \\
\hline Group methods (demonstration) & .080 & .313 & 0.066 \\
\hline Mass methods & .538 & .234 & $5.279^{* * *}$ \\
\hline Combination of individual and group methods & .163 & .278 & 0.344 \\
\hline Log-likelihood & 284.783 & & \\
\hline Pseudo R square & 0.60 & & \\
\hline Chi-square & $57.351^{* * *}$ & & \\
\hline
\end{tabular}

International Journal of Advanced Research in Botany (IJARB) 


\section{CONCLUSION}

The main thrust of this study was to assess the influence of extension teaching methods on adoption of innovations in the study area. Unfortunately, extension services have failed in performing its role efficiently and effectively. This agreed totally with Nwachukwu (2005) that the key to achieve the objectives of extension is the creation of a dynamic link between farmers, professional extension workers and researchers. The study has revealed that cassava /maize/ telferia inter-crop production package has not fully been adopted in the study area, therefore the extension agents has not done enough using the group and individual extension teaching methods. use of extension service delivery methods such as radio, farm and home visit, farmer training and print material are perceived as most effective respectively by the farmers. Further analysis show that the coefficient for mass method (ICT, $\mathrm{Tv} /$ radio broadcasts, posters/leaflets, mobile phones, etc) was positive and highly significant at $1 \%$ level of probability. This implies that increase in the use of mass method contrary to group method used by extension agents will lead to increase in adoption of agricultural innovations in the study area.

From the study, the following recommendation were made:

For agricultural extension in Nigeria to be effective, extension personnel must acquire the requisite knowledge and skills necessary for using modern ICTs in the discharge of their job functions.

\section{REFERENCES}

Akinagbe, A.O. (2010) Challenges of Farmer-Led Extension Approach in Nigeria. World Journal of Agricultural Sciences, 3, 353-359.

Ayesha, K. and Mohammad, A. (2012) Farmer's Perception of Extension Methods Used by Extension Personnel for Dissemination of New Agricultural Technologies in Kyber Pekhtunkhwa, Pakistan. Sarhad Journal of Agriculture, 28, 511-520.

Christoplos, I. (2010). Mobilising the Potential of Rural and Agricultural Extension. Neuchatel Group. Pp 4-5.

CTA (2013) ICTs - Transforming agricultural extension. An e-discussion.

Fabiyi, E. F. (2015). Impact of Agricultural Extension on Adoption of Soyabean Innovations in Bauchi, Nigeria. Case Studies Journa.l ISSN (2305-509X) - Volume 4, Issue 4 - April-2015. P 5.

Garba, I. (2008). Influence of Agricultural Extension Programme on Farmers' Agricultural production In Kano State.Thesis submitted to the school of postgraduate studies, Ahmadu Bello University, zaria, Nigeria. Pp $35-88$.

Nwachukwu, I. (2005). Agricultural Communication: Principles and Practice. Umuahia: lambhouse Publishers.

Umar, S., Musa, M. W., Olayemi, Y. T and Suleiman, R. (2015). Awareness and Use of Information and Communication Technologies among Extension Agents in Kaduna State of Nigeria. Journal of Agricultural Extension. Vol.19 (1) June, 2015. ISSN 24086851. Pp 7-9.

Umeh, O. J. (2016). Farmers Perception on Extension Service Delivery Methods in South East Nigeria: The Case of Farming Households in Abia State. Journal of Community and Communication Research. www.sccdr.org. Volume 1, No. 1 June 2016. Pp. 70-76.

Citation: O.J Umeh et al, " Assessment of Influence of Extension Teaching Methods on the Level of Adoption of Agricultural Innovation in Akwa-Ibom State, Nigeria ", International Journal of Advanced Research in Botany, vol. 4, no. 1, p. 1-6, 2018. http://dx.doi.org/10.20431/2455-4316.0401001

Copyright: () 2018 Authors. This is an open-access article distributed under the terms of the Creative Commons Attribution License, which permits unrestricted use, distribution, and reproduction in any medium, provided the original author and source are credited. 